ECONOMICS

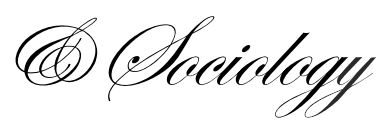

\author{
Tatjana Bilevičienè, \\ Department of Business Economics, \\ Faculty of Economics and Finance \\ Management, \\ Mykolas Romeris University, \\ Vilnius, Lithuania, \\ E-mail:tbilev@mruni.eu
}

Eglè Bilevičiūtè,

Department of Administrative Law and Procedure,

Faculty of Law,

Mykolas Romeris University,

Vilnius, Lithuania,

E-mail:eglek@mruni.eu

Gintarè Paražinskaitè, Faculty of Social Technologies, Institute of Digital Technologies, Mykolas Romeris University, Vilnius, Lithuania,

E-mail:giparaz@mruni.eu

Received: May, 2015

1st Revision: October, 2015

Accepted: December, 2015

DOI: $10.14254 / 2071-$

789X.2015/8-4/7

JEL Classification: C02, O32, E2
Bilevičienè T., Bilevičiūtė, E., Paražinskaitė, G. (2015), Innovative Trends in Human Resources Management, Economics and Sociology, Vol. 8, No 4, pp. 94-109. DOI: $10.14254 / 2071-789 X .2015 / 8-4 / 7$

\section{INNOVATIVE TRENDS IN HUMAN RESOURCES MANAGEMENT}

\begin{abstract}
Application of information technologies represents a heavily debated aspects of human resources management. The aim of this paper is to analyze how innovative human resource management could improve the quality and efficiency of human resources management. The article presents the results of expert evaluations carried out in the Personnel Administration Divisions of the Ministries of the Republic of Lithuania. This paper presents only a part of survey results and analysis of theoretical material. Following an information technology-based innovation, environmental analysis identified the need to strengthen and supplement the factors that encourage innovation, and reduce or eliminate factors that were slowing innovation. The results of our research show that the purposeful cycle of development of information technology as innovation implementation can lead to the effective application of information technology.
\end{abstract}

Keywords: innovation, information technologies, personnel administration, human resources management, effectiveness.

\title{
Introduction
}

Managing human resources activity has become quite difficult as information infrastructure must be continually updated, applied to a complex of changing activities linked to the environment according to industry-specific characteristics, and collectively respond to the needs of each company. During the preparation of this research, a comprehensive analysis of scientific literature was done, however for the sake of minimizing the length of this paper, only a part was presented. Existing e-government scientific achievements as well as other research approaches that are under development are of great importance when examining the public sector (Davison, 2005; Dawes, Cook, 2007; Millard, 2013; and others). 
Information technology and its application in public administration processes can cause social innovation, where innovation occurs both, as something entirely new or as a new combination of existing elements. Researchers from US, European and other universities around the world (Schuler, Jackson, 2007; Strohmeier, 2007; Joseph, Ezzedeen, 2008; Thom, Ritz, 2008; Walk et al., 2014) have developed research in information technologies and their implementation for human resources management.

The organization must learn rationally to direct information resources for their development, to integrate internal and external information flows and to combine the unique features of a particular company and its values with information technologies. Scientists have pointed out that (Griggs et al., 2015) human resources (HR) education is very important for successful implementation of innovations. Different opinions on research of information technologies application in human resources management are prevailing in the world of science (Analoui, 2007; Kavanagh, Thite, 2009; Bondarouk, Furtmueller, 2012; Altmann, Engberg, 2015; Katou, 2015; and others).

The purpose of this paper is to investigate application of information technologies in the process of innovative human resources management at the ministry level in the Republic of Lithuania.

Our research objectives were to conduct an expert evaluation (of staff from the personnel departments of the Ministries of the Republic of Lithuania) in order to determine the internal and external environment and innovation factors based on information technology, to evaluate these factors and how they affect the initiation and application of information technologies for human resources management activities.

Our research methodology includes a combination of theoretical and empirical methods. A case study helps towards achieving a comprehensive, exhaustive and detailed social component study. The expert evaluations used in a case study on the implementation of information technologies for human resources management at Ministries of the Republic of Lithuania. The collection of empirical data defines that with the help of experts, information technologies (IT) used to perform different functions for professionals including their attitudes or behavior towards it, the IT installation processes for human resources management (HRM) purposes, and the problematic issues and technology-related environmental factors involved. An expert-specialists' survey was conducted from July until September 2013. Then analysis of those results carried out within the context of efficiency.

This article has several practical implications-conclusions and recommendations were prepared only for the improvement of information technologies application in personnel administration offices in Ministries of the Republic of Lithuania. This paper presents only a part of the survey results. The first part of the article presents an analysis of different aspects of IT application in HRM. The second part of article presents an analysis of the efficiency of innovative methods of HRM. The third part of article explains the research methodology. The fourth part of article presents the research results. Finally, we present the conclusions and further development of opportunities of research.

\section{Information technology in context of human resources management's activities}

European Commission Strategy Paper Europe 2020 "A strategy for smart, sustainable and inclusive growth" states, that: "The targets are representative of the three priorities of smart, sustainable and inclusive growth but they are not exhaustive: a wide range of actions at national, EU and international levels will be necessary to underpin them. The Commission is putting forward seven flagship initiatives to catalyse progress under each priority theme" (European Commission, 2010). There are two key initiatives - "Innovation Union" - to improve framework conditions and access to finance for research and innovation so as to 
ensure that innovative ideas can be turned into products and services that create growth and jobs and - "A digital agenda for Europe" - to speed up the roll-out of high-speed internet and reap the benefits of a digital single market for households and firms" (European Commission, 2010).

Human Resources Management (HRM) - is the organizational function performed by the staff responsible for human resources (HR) management and covers a range of activities such as recruitment, training, remuneration and compensation, and legal issues (Joseph, Ezzedeen, 2008; Walk et al., 2014). Globalization, technology deployment and operation in the conditions of competition encourage continuous review and seeking of the most effective courses of action, to follow global trends and by it to adapt or improve them. Directing human resource management requires a necessity to use modern techniques and relying on the latest HR management researches results (Thom, Ritz, 2008; Altmann, Engberg, 2015; Katou, 2015).

Human Resources Management - is a specific management area, which can be subject to different information technology. Scientists (Joseph, Ezzedeen, 2008; Yamamoto, Ozbek, 2008) electronic human resources management defines as human resources management process's implementation and simplification by the operation on the Internet network based technology. Strohmeier (2007) electronic human resources management technologies' definition extends by suggesting that it could be any of the information technology for the design, implementation, and communication of the human resources management functions.

According to Analoui (2007), e-HRM's benefits are a way of reducing the number of tasks, solving a lot of routine administrative work, and helping to organize more effective and efficient work methods for both managers' and employees' activities. However, there is no answer to the question regarding the type of HRM activities that information technology can be utilized for. "For improving organizational performance, managers and decision makers should make their HRM systems more visible, understandable, legitimate and relevant" (Katou, 2015). HR professionals must not only focus on the needs of existing employees, but also prepare workers for the future, to take care of administrative efficiency, and apply their knowledge in improving the decision results, in order to strengthen more confidence in the leadership (Garcia-Carbonell, 2015).

Scientists (Ruël, Bondarouk, Looise, 2004; Kavanagh, Thite, 2009) counter by offering three purposes of e-HRM: (1) improving the strategic orientation of HRM, (2) reduction of costs/ increase of effectiveness, (3) improvement of services for customers/ release for managers and employers. In addition to knowing what should be the management of human resources and what possibilities are offered by new information technologies, it is important to determine how successful to implement such innovation. The internal and external environment's analysis and capacity development for more successfully making innovation are key criteria that must be taken into account (Habibizad Navin et al., 2014).

\section{Innovative human resource management in the context of efficiency}

The scientific literature assigns the criteria: effectiveness, efficiency and economy. Effectiveness is define as the level of purposes' achievement or planned and actual consequences of a particular activity ratio. Effectiveness is a top-level criterion because it includes summary of efficiency criteria, to establish for each of the criterion the influence on results of performance, to evaluate the level of assess achievement of the objectives (Puškorius, 2004).

Effectively to manage people is important for seeking improvement of the quality of the organization's activities. Today, public sector efficiency are often seen not only as an institutional performance improvement, but how the system of elements, including political 
influence level, political and managerial behavior changes, harmonization the of interest groups options, ensuring of a consistent regulatory environment and a stable legal framework, the development of implementation and evaluation methodologies and so on (Petrauskiene, Raipa, 2012). Therefore, the efficiency (and also the effectiveness) can be achieved by various methods and techniques: changes in work processes, employee behavioral changes, and change in the management process (Altmann, Engberg, 2015).

In answering the question of evaluation of effectiveness and efficiency of human resource management, we may differ the economic and social objectives. Their interface called economic and social efficiency and effectiveness (Schuler, Jackson, 2007). Other authors (Codagnone, Undheim, 2008; Lengnick-Hall et al., 2009) started the efficiency and effectiveness links with the three components of public services' value chain: input, output, outcomes and contextual variables. This approach can be complement by the insights of application of IT in human resources management.

The Strategic Management Manual defines the innovation as a new or improved idea or model acquired economic substance over a new product, commercial interactions of process or system. Hidalgo and Albors (2008) points two main purposes of innovations management: (1) effectively to manage the innovations, to create variety of new suggestions and (2) effectively to manage human resources. "Technology innovation can essentially be understood as an ongoing process of interpretation and sense making and is thus a cognitive

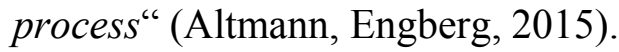

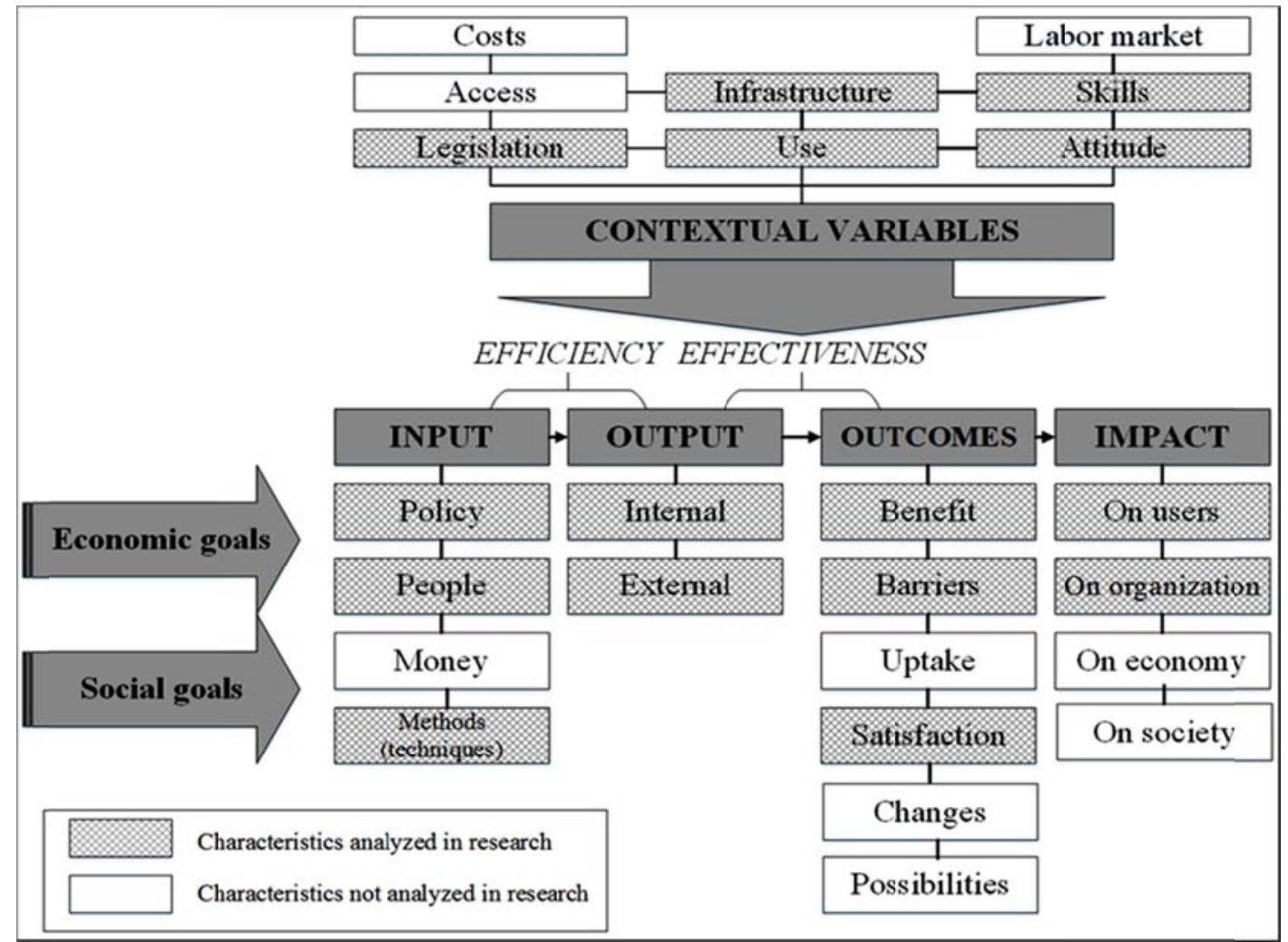

Figure 1. IT application effectiveness context for the innovative analysis of the human resource management

Source: compiled by the authors according to Ruel et al. (2004); Codagnone, Undheim (2008); Reddington et al. (2011); Šalčius, Šarkiūnaitė (2011); Petrauskienė, Raipa (2012).

Researchers at McKinsey Global Institute defines social technologies as any products or services allowing the social interaction in the digital environment (Chui et al., 2012). 
Social technology - is the innovation that has changed the social processes and made them more efficient (Altmann, Engberg, 2015; Skaržauskienè et al., 2013; Solberg Soilen, Tontini, 2013). Growth and innovation are possible only if social technology provides creation and further development of new technologies (Leibetseder, 2011; Katou, 2015). Approach to information technologies as the innovation in the organization and identification of place of technology in innovation systems help determine which of the theoretical backgrounds of innovations science rules can be apply to public sector HR management office in research of technology environment. IT implementation is not a terminative process; rather it is every new usage of contextual and non-permanent systems. Each implementation can be a treated as a new IT experience and their complexities could be treat as terminative until users feel more comfortable using a particular IT. The support for the user should be ensure (Ruël et al., 2004; Orlikowski, 2000). According to the innovations 'diffusion theory, innovations in essence are implement at two levels: the individual and organizational (Altmann, Engberg, 2015). According to Rogers (2003), most often people will not accept until the organization has implemented it. Yet, implementation of innovation at the organizational level is more complicated than implementation of innovation at individual level due to the number of individuals needed at the same time. Each individual has his role during this process, yet at the not only everyone has changed, but the organization as well.

Summarizing the theoretical insights, we can create IT application effectiveness context for the innovative analysis of the human resource management scheme (see Figure 1).

Quality of human resource management determined by the efficiency of the application of information technology. Improving its effectiveness is the background of the HR management improvement. This study focused on the determining factors of effectiveness: social objectives, the legal and political framework for internal and external outputs, results and impact of such contextual factors as infrastructure, usage, capacity value. These include the environment (legal, political, socio-cultural), the functional and structural evaluation dimensions. No separate elements affect the overall application of efficiency, but it is their complexities, therefore the positives should be maximize and negatives reduced. Structure of the factors listed in Table 1.

Table 1. Environmental factors influencing IT innovation

\begin{tabular}{|c|c|c|c|}
\hline $\begin{array}{c}\text { Factors } \\
\text { type }\end{array}$ & Subspecies & No & Statement in the research tool \\
\hline 1 & 2 & 3 & 4 \\
\hline \multirow{14}{*}{ 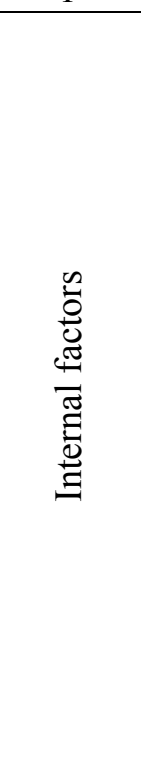 } & \multirow{4}{*}{$\begin{array}{c}\text { Individual } \\
\text { characteristics }\end{array}$} & S1 & Direct superior's approach to information technology \\
\hline & & S2 & Employee attitude to information technology \\
\hline & & S5 & The employee's ability to use information technologies \\
\hline & & S6 & $\begin{array}{l}\text { Information Technology operating risk (eg. fear of making a } \\
\text { mistake, fear of the consequences of errors, etc.). }\end{array}$ \\
\hline & \multirow{6}{*}{$\begin{array}{l}\text { Organizations' } \\
\text { properties }\end{array}$} & S11 & Organization's decentralization \\
\hline & & S14 & Organizations formalization \\
\hline & & S15 & The personnel department size \\
\hline & & S16 & Personnel Administration Division serviced staff \\
\hline & & S12 & Organization's climate \\
\hline & & S13 & Personnel Administration Division organizational climate \\
\hline & \multirow{4}{*}{$\begin{array}{l}\text { Technological } \\
\text { environment }\end{array}$} & S7 & Information Technology Security \\
\hline & & S8 & Information technology benefits for activities \\
\hline & & S9 & Direct contact support learning to use information technology \\
\hline & & S10 & $\begin{array}{l}\text { Guaranteed technical support (ability to consult) after the } \\
\text { introduction of innovations }\end{array}$ \\
\hline
\end{tabular}




\begin{tabular}{|c|c|c|c|}
\hline 1 & 2 & 3 & 4 \\
\hline \multirow{6}{*}{ 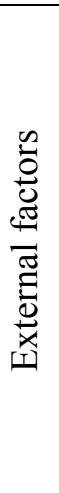 } & \multirow{4}{*}{$\begin{array}{l}\text { Socio-political } \\
\text { environment }\end{array}$} & $\mathrm{S} 17$ & $\begin{array}{l}\text { External bodies' (eg. Ministry, Government) acceptance, support } \\
\text { and financial conditions }\end{array}$ \\
\hline & & $\mathrm{S} 19$ & $\begin{array}{l}\text { Publicity of performance of the organization (publicity measures, } \\
\text { the degree of publicity) }\end{array}$ \\
\hline & & S20 & $\begin{array}{l}\text { Political direction's change (strategic priorities and political } \\
\text { confidence in the staff changes because of the ruling power change) }\end{array}$ \\
\hline & & $\mathrm{S} 18$ & $\begin{array}{l}\text { The availability of new sources of work (where are looking for and } \\
\text { what comes to work) }\end{array}$ \\
\hline & \multirow{2}{*}{$\begin{array}{c}\text { Human } \\
\text { resource } \\
\text { characteristics }\end{array}$} & S3 & HR Education \\
\hline & & S4 & The demographic situation \\
\hline
\end{tabular}

Source: own work.

Through theoretical analysis, we identified the key in e-government theory mentioned groups of factors (external and internal conditions) which complemented by determinants of innovation diffusion theory and determinants of technological factors making consumer's behavior theory. Also included were factors specifically related to IT adoption/rejection, described in other studies (by direct contact with a support technician installing it, the opportunity to consult after installation and so on).

Analyzing the legal and political environment, the basics of IT innovation were determined. From a policy perspective, use and development of innovation is encouraged, especially when it focused on the creativity of human resources, because it seeks to develop creative and an innovative society as well as broad-based innovations (including technology, public, inter-institutional cooperation).

The study sought to answer the question - What is the current use of IT-based human resources management in the personnel administration offices of the Ministries of the Republic of Lithuania innovative and what changes are needed to make it more innovative. An unambiguous answer to the question is not possible, the chapter aims to raise debate and discuss different aspects related to innovativeness, which were disclose by an empirical investigation.

\section{Empirical research methodology}

For implementation of the assessment made by experts from Lithuania Republic ministries, the expert assessment method selected. The questionnaire given to the highest level of operational units of Personnel Administration Staff of State Ministries - to HR management professionals (hereinafter called - the experts - professionals). The occupational status, academic degree, a certain scientific and practical work experience were the indicators of expert competence.

For this level of investigation, it was decide to examine the experts that were directly involved with the use of IT and HR management activities, and through which these services are provide. It was decide to implement research without outside experts, since they did not understand the specifics of working in this field. An expert-survey was conduct in July September 2013. Analysis of the results carried out through the context of effectiveness. Expert opinions compatibility was tested for responses to each question, calculating the Kendall's concordance coefficient W. It is believed that the appropriate expert compatibility is where $\mathrm{W} \geq 0.5$. This paper presents only a part of survey results.

Questions based on theoretical analysis. Based on the theoretical analysis there were distinguished the groups of factors influencing development of information technologies 
(internal and external), there were distinguished the subspecies of factors and to each subspecies specific factors were assigned (see Table 1). Experts asked by two questions with purpose to find out the influence of internal and external factors on innovation.

Question 1: Please evaluate the below listed reasons' influence on the success installation of the information technology project. The experts had to evaluate the factors on the ten-point system from 1 to 10 points, where 1 means that the relevant factor does not affect the information technology project deployment stages, 10 - where is the biggest influence of factor.

Question 2: Please specify are the following problems encouraging or inhibiting the deployment of information technology project. In this case, there was seeking to determine the same importance of the factors of adjustment affect's strength, depending on the nature of the influence (factor impends -1 ; neither hinders nor promotes -2 , can stop and promote -3 ; encourages -4 ) on information technology project implementation.

Experts' evaluation required to achieve compatibility of experts. Experts' compatibility is assessed by the of Kendall concordance coefficient W. In this case, there is only a minimal overall experts' opinions compatibility $W=0,5002$, p-level $=0,003$. The concordance rate is significantly different from zero.

\section{Analysis of the research's results}

On the first stage of results' processing were calculated averages for each factor estimates (see Table 2).

Table 2. Experts' evaluation averages. Influence of factors on the success installation of the information technology project

\begin{tabular}{|c|c|c|c|c|c|c|c|c|c|c|c|c|c|c|c|c|c|c|c|c|}
\hline & \multicolumn{20}{|c|}{ Factors } \\
\hline & $\bar{n}$ & $\tilde{\omega}$ & $\tilde{\omega}$ & $\ddot{\omega}$ & $\tilde{n}$ & ש & $\hat{n}$ & $\stackrel{\infty}{\infty}$ & हे & $\stackrel{0}{\sim n}$ & $\overline{\bar{n}}$ & $\frac{\sim}{\sim n}$ & $\frac{m}{\tilde{n}}$ & $\frac{\nabla}{\tilde{\sigma}}$ & $\frac{n}{i s}$ & $\frac{0}{\tilde{n}}$ & $\bar{n}$ & $\frac{\infty}{\sim}$ & $\frac{\sigma}{\dot{n}}$ & $\begin{array}{l}\text { ๙ิ } \\
\text { ஸิ }\end{array}$ \\
\hline 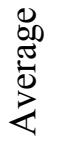 & aू & $m_{\infty}^{\infty}$ & $\stackrel{\infty}{0}^{\infty}$ & $\hat{\sigma}_{0}$ & $\stackrel{\infty}{\sim}$ & ఫै & $\stackrel{\infty}{\sim}$ & $\hat{\infty}$ & $\stackrel{2}{\sim}$ & $\hat{\infty}$ & $\theta_{0}^{0}$ & $\stackrel{\circ}{r}$ & $\stackrel{2}{2}$ & $\ddot{6}$ & $\hat{n}$ & $\hat{\sigma}$ & $\stackrel{2}{\sim}$ & $\tilde{\sigma}^{n}$ & $\begin{array}{l}\infty \\
n \\
n\end{array}$ & $\begin{array}{l}\infty \\
n\end{array}$ \\
\hline
\end{tabular}

Source: own work.

Summarizing the averages of values' calculation results we could suggest that although individual experts some of the factors assessed as having the greatest impact (10 points rating), but in the overall context (based on the total average of expertise and individual experts group evaluations' average) no one factor is considered as the most important, causing the greatest impact. The experts by 8-9 scoring evaluated the significance of the following factors: Direct superior's approach to information technology and Employee attitude to information technology - these factors belonging to the group of Individual properties. From the technological environment, two factors are also evaluated as the most contributing to the success of IT innovation implementation - it is Information Technology benefits for activities and Guaranteed technical support (ability to consult) after the introduction of innovations. These factors are mentioned both as in open-ended questions as well as those granted by great importance in the innovation process.

The obvious is the group of factors which by experts are not relevant to the innovation process. This, in particular, external factors and socio-political environment factors: Publicity 
of the performance activity of the organization (publicity measures, the degree of publicity), Change of political direction (changes of strategic priorities and political confidence staff caused by the ruling power change) and The availability of new work sources (where is looking for and who comes to work) and external factors of group Human resource characteristics, i.e., describing the labour complexity of the factors: education and the demographic situation. Analogous views are respected and in the scientific literature.

Therefore, the continuation of such studies should take into account the factors held as potentially affecting (for example, to assess by the range of 10-7, the general consensus or experts' evaluation although is lower in separate groups, but is staying outside this range), that are questionable and should be included in consideration of the particular situation (the overall average is 6-7, some experts' groups have lower ratings), and which in general should be dismissed (unanimously lower than 6 evaluations). Based on these experts' survey, the matrix of factors summarizing the suitability for further research shows that no one factor by experts' consensus was not rejected as ineffective (see Table 3).

Table 3. Experts' evaluation scoreboard. Influence of factors on the success installation of the information technology project

\begin{tabular}{|c|c|c|c|c|c|c|c|c|c|c|c|c|c|c|c|c|c|c|c|c|}
\hline \multirow{2}{*}{ 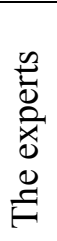 } & \multicolumn{20}{|c|}{ Factors } \\
\hline & $\bar{n}$ & $\tilde{W}$ & $\tilde{n}$ & $\ddot{\varpi}$ & $\tilde{n}$ & ڤ & is & $\stackrel{\infty}{\infty}$ & ڤे & $\frac{\circ}{\sim s}$ & $\overline{\bar{n}}$ & $\frac{\sim}{\sim S}$ & $\frac{m}{n}$ & $\frac{\nabla}{\sim}$ & $\frac{n}{n}$ & $\frac{6}{\sim}$ & $\bar{\sim}$ & $\frac{\infty}{\sim}$ & $\frac{\sigma}{\infty}$ & ๙ิ \\
\hline 1 & 9 & 8 & 5 & 4 & 8 & 7 & 8 & 8 & 6 & 9 & 7 & 6 & 6 & 6 & 4 & 4 & 5 & 5 & 3 & 3 \\
\hline 2 & 9 & 9 & 5 & 6 & 8 & 7 & 6 & 8 & 7 & 9 & 8 & 8 & 7 & 6 & 5 & 8 & 8 & 7 & 6 & 5 \\
\hline 3 & 10 & 10 & 8 & 5 & 10 & 5 & 10 & 10 & 8 & 8 & 5 & 5 & 5 & 5 & 5 & 10 & 5 & 5 & 5 & 5 \\
\hline 4 & 8 & 8 & 5 & 5 & 5 & 5 & 5 & 10 & 10 & 10 & 5 & 7 & 5 & 5 & 5 & 5 & 5 & 5 & 5 & 7 \\
\hline 5 & 10 & 10 & 7 & 7 & 7 & 7 & 10 & 8 & 8 & 10 & 8 & 6 & 6 & 6 & 6 & 6 & 6 & 8 & 8 & 5 \\
\hline 6 & 9 & 6 & 7 & 4 & 6 & 6 & 7 & 8 & 7 & 8 & 2 & 6 & 9 & 7 & 8 & 7 & 9 & 5 & 6 & 8 \\
\hline 7 & 10 & 10 & 10 & 10 & 8 & 8 & 10 & 10 & 10 & 10 & 7 & 8 & 9 & 8 & 10 & 10 & 10 & 8 & 8 & 8 \\
\hline 8 & 7 & 7 & 8 & 8 & 8 & 5 & 5 & 8 & 8 & 8 & 7 & 6 & 7 & 7 & 4 & 4 & 7 & 8 & 6 & 6 \\
\hline 9 & 10 & 8 & 8 & 8 & 9 & 5 & 10 & 10 & 5 & 10 & 10 & 10 & 10 & 10 & 10 & 10 & 10 & 9 & 10 & 10 \\
\hline 10 & 9 & 9 & 8 & 7 & 9 & 8 & 8 & 8 & 8 & 5 & 6 & 7 & 8 & 7 & 6 & 7 & 7 & 7 & 5 & 5 \\
\hline 11 & 9 & 8 & 6 & 5 & 7 & 7 & 7 & 8 & 5 & 9 & 7 & 8 & 8 & 7 & 6 & 7 & 9 & 6 & 6 & 5 \\
\hline 12 & 10 & 7 & 5 & 3 & 8 & 7 & 7 & 8 & 5 & 8 & 7 & 7 & 7 & 5 & 2 & 2 & 5 & 5 & 2 & 3 \\
\hline
\end{tabular}

Source: own work.

The second stage of study results processing was to summarize estimates collected during the experts' evaluation (replies of Question 1 and Question 2) and the Multiple-criteria Decision Analysis (MCDA) used. Any structured method for a set of possible alternatives championship could be assign to the multiple methods analysis group. Multiple criteria analysis method facilitates decision-making, when factors cannot be assess in quantitative terms. For alternatives, there is assign a correlation for that criteria. The criteria may be quantitative and qualitative, or objective and subjective. Compound (constructed) criteria are not of common interpretation, but we could design its measurement scale, for example, from 1 to 10 and in this way we can measure its size. Such a measure is subjective. In MCDA process, various methods are implement helping to calculate points, to rank and weight the criteria (eg. as in this case - experts' evaluation). Results of experts' evaluation presented in the form of a matrix (see Table 3 and Table 4). 
Table 4. Experts' evaluation scoreboard. Relevance of indicators

\begin{tabular}{|c|c|c|c|c|c|c|c|c|c|c|c|c|c|c|c|c|c|c|c|c|c|}
\hline \multirow{2}{*}{ 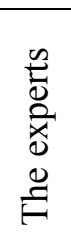 } & \multicolumn{21}{|c|}{ Factors } \\
\hline & $\bar{n}$ & బิ & $\tilde{n}$ & 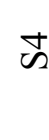 & $\tilde{n}$ & $v$ & $\hat{\infty}$ & $\stackrel{\infty}{\infty}$ & हे & $\frac{0}{\pi}$ & & & $\frac{\sim}{\sim n}$ & $\frac{m}{n}$ & $\frac{\Delta}{\sim}$ & $\frac{n}{n}$ & $\frac{\sigma}{\pi}$ & $\bar{n}$ & $\frac{\infty}{\pi s}$ & $\stackrel{\ominus}{\vec{n}}$ & ๙ิ \\
\hline 1 & 2 & 2 & 2 & 2 & 1 & 1 & 4 & 3 & 3 & 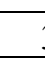 & & 2 & 2 & 2 & 2 & 4 & 4 & 4 & 2 & 3 & 2 \\
\hline 2 & 3 & 4 & 4 & 2 & 2 & 1 & 2 & 3 & 4 & & & 4 & 2 & 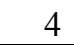 & 4 & 4 & 4 & 2 & 4 & 4 & 3 \\
\hline 3 & 3 & 3 & 4 & 4 & 4 & 3 & 3 & 3 & 3 & 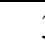 & & 4 & 4 & 4 & 4 & 4 & 3 & 3 & 4 & 4 & 3 \\
\hline 4 & 3 & 2 & 2 & 2 & 2 & 1 & 4 & 3 & 3 & . & & 1 & 2 & 4 & 4 & 4 & 4 & 4 & 4 & 4 & 3 \\
\hline 5 & 2 & 2 & $\underline{4}$ & 2 & 3 & 2 & 1 & 3 & 3 & 2 & & 3 & 3 & 3 & 4 & 4 & 3 & 4 & 3 & 3 & 2 \\
\hline 6 & 3 & 3 & 3 & 2 & 3 & 2 & 2 & 3 & 3 & & & 2 & 3 & 3 & 2 & 2 & 2 & 3 & 3 & 2 & 3 \\
\hline 7 & 2 & 1 & 2 & 2 & 3 & 2 & 2 & 3 & 3 & 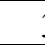 & & 2 & 2 & 2 & 2 & 2 & 2 & 2 & 3 & 3 & 2 \\
\hline 8 & 4 & 3 & 3 & 4 & 2 & 4 & 2 & 2 & 3 & 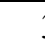 & & 3 & 4 & 4 & 4 & 4 & 4 & 4 & 3 & 4 & 4 \\
\hline 9 & 2 & 2 & 2 & 2 & 2 & 1 & 2 & 3 & 3 & 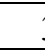 & & 1 & 1 & 1 & 4 & 2 & 2 & 2 & 2 & 2 & 2 \\
\hline 10 & 3 & 3 & 3 & 4 & 3 & 1 & 4 & 3 & 3 & 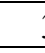 & & 4 & 3 & 3 & 4 & 4 & 4 & 4 & 4 & 3 & 3 \\
\hline 11 & 3 & 3 & 4 & 4 & 3 & 1 & 2 & 3 & 3 & 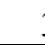 & & 4 & 2 & 2 & 4 & 4 & 4 & 3 & 4 & 4 & 3 \\
\hline 12 & 2 & 2 & 4 & 3 & 1 & 1 & 4 & 2 & 3 & 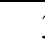 & & 4 & 2 & 4 & 2 & 4 & 4 & 2 & 2 & 3 & 2 \\
\hline
\end{tabular}

Source: own work.

Each factor's relative estimate may be calculated in two ways: either by the assessment of each of these factors affect on the estimates (answers to Question 1), or by a complex assessment of and an impact factor (answers to Question 1), and estimates of importance of factor (answers to Question 2). In this case, the strength of influence adjusted, depending on the nature of the impact (inhibits; promotes; does not affect, and is braking and promote).

Matrix of estimates of factors' influence (Question 1) is presented in Table 5. Factors' importance's estimates matrix (Question 2) is presented in Table 6.

Table 5. Experts' evaluation scoreboard. Estimates of factors' influence

\begin{tabular}{llllllll}
\hline & \multicolumn{7}{c}{ Factors } \\
\hline Expert & 1 & 2 & 3 & 4 & $\ldots$ & $\mathrm{m}-1$ & $\mathrm{~m}$ \\
\hline 1 & $\mathrm{x}_{11}$ & $\mathrm{x}_{12}$ & $\mathrm{x}_{13}$ & $\mathrm{x}_{14}$ & $\ldots$ & $\mathrm{x}_{1(\mathrm{~m}-1)}$ & $\mathrm{x}_{1 \mathrm{~m}}$ \\
\hline 2 & $\mathrm{x}_{21}$ & $\mathrm{x}_{22}$ & $\mathrm{x}_{23}$ & $\mathrm{x}_{24}$ & $\ldots$ & $\mathrm{x}_{2(\mathrm{~m}-1)}$ & $\mathrm{x}_{2 \mathrm{~m}}$ \\
\hline 3 & $\mathrm{x}_{31}$ & $\mathrm{x}_{32}$ & $\mathrm{x}_{33}$ & $\mathrm{x}_{34}$ & $\ldots$ & $\mathrm{x}_{3(\mathrm{~m}-1)}$ & $\mathrm{x}_{3 \mathrm{~m}}$ \\
\hline 4 & $\mathrm{x}_{41}$ & $\mathrm{x}_{42}$ & $\mathrm{x}_{43}$ & $\mathrm{x}_{44}$ & $\ldots$ & $\mathrm{x}_{4(\mathrm{~m}-1)}$ & $\mathrm{x}_{4 \mathrm{~m}}$ \\
\hline$\ldots$ & $\ldots$ & $\ldots$ & $\ldots$ & $\ldots$ & $\ldots$ & $\ldots$ & $\ldots$ \\
\hline $\mathrm{n}-1$ & $\mathrm{x}_{(\mathrm{n}-1) 1}$ & $\mathrm{x}_{(\mathrm{n}-1) 2}$ & $\mathrm{x}_{(\mathrm{n}-1) 3}$ & $\mathrm{x}_{(\mathrm{n}-1) 4}$ & $\ldots$ & $\mathrm{x}_{(\mathrm{n}-1) 1(\mathrm{~m}-1)}$ & $\mathrm{x}_{(\mathrm{n}-1) \mathrm{m}}$ \\
\hline $\mathrm{n}$ & $\mathrm{x}_{\mathrm{n} 1}$ & $\mathrm{x}_{\mathrm{n} 2}$ & $\mathrm{x}_{\mathrm{n} 3}$ & $\mathrm{x}_{\mathrm{n} 4}$ & $\ldots$ & $\mathrm{x}_{\mathrm{n}(\mathrm{m}-1)}$ & $\mathrm{x}_{\mathrm{nm}}$ \\
\hline
\end{tabular}

Source: own work.

Here $x_{i j}$ - factor significance estimates, where $i=1, \ldots, n, j=1, \ldots, m$. In this case $n=12$, o $m=20$.

The normalized estimator:

$$
x_{i j}^{\prime}=\frac{x_{i j}-x_{i j v i n}}{x_{i j \max }-x_{i j \min }} ; s_{i j}^{\prime}=\frac{x_{i j}-x_{i j v i n}}{x_{i j \max }-x_{i j \min }}, \text { here } i=1, \ldots, n, j=1, \ldots, m
$$


Table 6. Experts' evaluation scoreboard. Estimates of factors' importance

\begin{tabular}{llllllll}
\hline \multicolumn{7}{c}{ Factors } \\
\hline Expert & 1 & 2 & 3 & 4 & $\ldots$ & $\mathrm{m}-1$ & $\mathrm{~m}$ \\
\hline 1 & $\mathrm{~s}_{11}$ & $\mathrm{~s}_{12}$ & $\mathrm{~s}_{13}$ & $\mathrm{~s}_{14}$ & $\ldots$ & $\mathrm{s}_{1(\mathrm{~m}-1)}$ & $\mathrm{s}_{1 \mathrm{~m}}$ \\
\hline 2 & $\mathrm{~s}_{21}$ & $\mathrm{~s}_{22}$ & $\mathrm{~s}_{23}$ & $\mathrm{~s}_{24}$ & $\ldots$ & $\mathrm{s}_{2(\mathrm{~m}-1)}$ & $\mathrm{s}_{2 \mathrm{~m}}$ \\
\hline 3 & $\mathrm{~s}_{31}$ & $\mathrm{~s}_{32}$ & $\mathrm{~s}_{33}$ & $\mathrm{~s}_{34}$ & $\ldots$ & $\mathrm{s}_{3(\mathrm{~m}-1)}$ & $\mathrm{s}_{3 \mathrm{~m}}$ \\
\hline 4 & $\mathrm{~s}_{41}$ & $\mathrm{~s}_{42}$ & $\mathrm{~s}_{43}$ & $\mathrm{~s}_{44}$ & $\ldots$ & $\mathrm{s}_{4(\mathrm{~m}-1)}$ & $\mathrm{s}_{4 \mathrm{~m}}$ \\
\hline$\ldots$ & $\ldots$ & $\ldots$ & $\ldots$ & $\ldots$ & $\ldots$ & $\ldots$ & $\ldots$ \\
\hline $\mathrm{n}-1$ & $\mathrm{~s}_{(\mathrm{n}-1) 1}$ & $\mathrm{~s}_{(\mathrm{n}-1) 2}$ & $\mathrm{~s}_{(\mathrm{n}-1) 3}$ & $\mathrm{~s}_{(\mathrm{n}-1) 4}$ & $\ldots$ & $\mathrm{s}_{(\mathrm{n}-1) 1(\mathrm{~m}-1)}$ & $\mathrm{s}_{(\mathrm{n}-1) \mathrm{m}}$ \\
\hline $\mathrm{n}$ & $\mathrm{s}_{\mathrm{n} 1}$ & $\mathrm{~s}_{\mathrm{n} 2}$ & $\mathrm{~s}_{\mathrm{n} 3}$ & $\mathrm{~s}_{\mathrm{n} 4}$ & $\ldots$ & $\mathrm{s}_{\mathrm{n}(\mathrm{m}-1)}$ & $\mathrm{s}_{\mathrm{nm}}$ \\
\hline
\end{tabular}

Source: own work.

Here $s_{i j}$ - factor significance estimates, where $i=1, \ldots, n, j=1, \ldots, m$. In this case $n=12$, o $m=20$.

Method 1. There were analysing only factors' evaluations, as the results from the answers to question 1 .

In this case, $n$ experts evaluated $m$ alternatives by using the same scale. Their assessment result - matrix $\left\|x_{i j}\right\|, i=1, \ldots, n ; j=1, \ldots, m$, where $\left\|x_{i j}\right\|$ - matrix of all factors' evaluation by all experts; $x_{i j}-i$ - th expert $j$ - th factor estimate; $i=1, \ldots, n, j=1, \ldots, m$; in this case $n=12$, o $m=20$.

The factor's relative importance coefficient $I_{j}^{t}$ was evaluated as a first step in an iterative manner to $t=0$ giving for coefficients the equal weighting values: $I_{j}^{0}=1 / \mathrm{m}$, $j=1, \ldots, m$.

A further step $t=1,2, \ldots$ important coefficients were adjusted by formulas (Dzemyda et al., 2007):

$$
\begin{gathered}
x_{i}^{t}=\sum_{j=1}^{m} I_{j}^{t-1} \cdot x_{i j}, j=1, \ldots, \mathrm{m} \\
S^{t}=\sum_{i=1}^{n} \sum_{j=1}^{m} x_{i}^{t} \cdot x_{i j} \\
I_{j}^{t}=\frac{1}{S^{t}} \cdot \sum_{i=1}^{n} x_{i}^{t} \cdot x_{i j}, \sum_{j=1}^{m} I_{j}^{t}=1,
\end{gathered}
$$

here:

$x_{i j}-i$ - th expert $j$ - th factor estimate;

$x_{i}^{t}-t$ iteration of $i$ - th expert estimate;

$i=1, \ldots, n, j=1, \ldots, m$; in this case $n=12$, o $m=20$;

$S^{t}-t$ iteration of sum of all factors;

$I_{j}^{t}-t$ iteration of $j$ factor's relative importance coefficient, calculations are repeating till the such condition: $\left|I_{j}^{t}-I_{j}^{t-1}\right|<\varepsilon=0,05$ would be reached; 
$\varepsilon-$ chosen precision of calculation.

Calculation results are presented in Table 7.

Method 2. Combining experts' assessments of questions 1 and 2, a synthetic indicator is calculated. In this case, the criteria values are aggregated to give the total value on the basis of it the factors were assessed. The total value for the factor $a$ is calculated as:

$$
Q_{j}\left(a_{j}\right)=\sum_{i=1}^{n} q_{i j}
$$

here $Q_{j}\left(a_{j}\right)$ - the total value for the factor $a_{j}$,

$q_{i j}=x_{i j} s_{i j}$ - instantaneous value of criterion,

$x_{i j}$ - estimate of the significance of factors,

$s_{i j}$ - estimates of importance of factors,

$i=1, \ldots, n, j=1, \ldots, m$.

Criterion (experts' evaluation) weight can be calculated as:

$$
W_{j}=\frac{Q_{j}\left(a_{j}\right)}{\sum_{j=1}^{m} Q_{j}\left(a_{j}\right)},
$$

Calculation results are presented in Table 7.

Table 7. Results of during empirical research used technologization environmental factors

\begin{tabular}{|c|c|c|c|}
\hline \multirow{2}{*}{ No } & \multirow{2}{*}{ Factors } & 1 method & 2 method \\
\hline & & \multicolumn{2}{|c|}{ Relative value of factor } \\
\hline 1 & 2 & 3 & 4 \\
\hline S1 & Direct superior's approach to information technology & 0,06 & 0,08 \\
\hline $\mathrm{S} 2$ & Employee attitude to information technology & 0,06 & 0,06 \\
\hline S3 & HR Education & 0,05 & 0,06 \\
\hline S4 & The demographic situation & 0,04 & 0,04 \\
\hline S5 & The employee's ability to use information technologies & 0,05 & 0,05 \\
\hline S6 & $\begin{array}{l}\text { Information Technology operating risk (eg. fear of making a } \\
\text { mistake, fear of the consequences of errors, etc.). }\end{array}$ & 0,04 & 0,01 \\
\hline S7 & Information Technology Security & 0,05 & 0,05 \\
\hline S8 & Information technology benefits for activities & 0,06 & 0,08 \\
\hline S9 & Direct contact support learning to use information technology & 0,05 & 0,07 \\
\hline S10 & $\begin{array}{l}\text { Guaranteed technical support (ability to consult) after the } \\
\text { introduction of innovations }\end{array}$ & 0,06 & 0,09 \\
\hline S11 & Organization's decentralization & 0,05 & 0,04 \\
\hline S12 & Organization's climate & 0,05 & 0,04 \\
\hline S13 & Personnel Administration Division organizational climate & 0,05 & 0,06 \\
\hline S14 & Organizations formalization & 0,05 & 0,05 \\
\hline S15 & The personnel department size & 0,04 & 0,02 \\
\hline S16 & Personnel Administration Division serviced staff & 0,05 & 0,04 \\
\hline S17 & $\begin{array}{l}\text { External bodies' (eg. Ministry, Government) acceptance, support } \\
\text { and financial conditions }\end{array}$ & 0,05 & 0,07 \\
\hline S18 & $\begin{array}{l}\text { The availability of new sources of work (where are looking for } \\
\text { and what comes to work) }\end{array}$ & 0,05 & 0,05 \\
\hline
\end{tabular}
relative valuation by multiple criteria complex proportional evaluation method 


\begin{tabular}{clcc}
\hline \multicolumn{1}{c}{2} & 3 & 4 \\
\hline S19 & $\begin{array}{l}\text { Publicity of performance of the organization (publicity measures, } \\
\text { the degree of publicity) }\end{array}$ & 0,04 & 0,03 \\
\hline S20 & $\begin{array}{l}\text { Political direction's change (strategic priorities and political } \\
\text { confidence in the staff changes because of the ruling power } \\
\text { change) }\end{array}$ & 0,04 & 0,02 \\
\hline & Total & 1,00 & 1,00 \\
\hline
\end{tabular}

Source: own work.

In assessing the importance of the factors according the calculated relative values, it is assumed that the equivalent relative importance of the 20 factors would be $1 / 20$ or $W j=0.05$.

After calculation by the first method it was found that 4 out of the 20 factors have greater than average value (Direct superior approach to information technology, Employee attitude to information technology, Information technology benefits, Guaranteed technical support (ability to consult) after the introduction of innovations) and another ten factors proved that $W j=0.05$, has an average value. When compared with the others, Five of the 20 factor according to experts, have reduced importance in the installation of information technology-based innovation - this is the demographic situation, the risk of usage, department size and socio-political elements of the environment such as the publicity of the performance of organization activities and change in political direction.

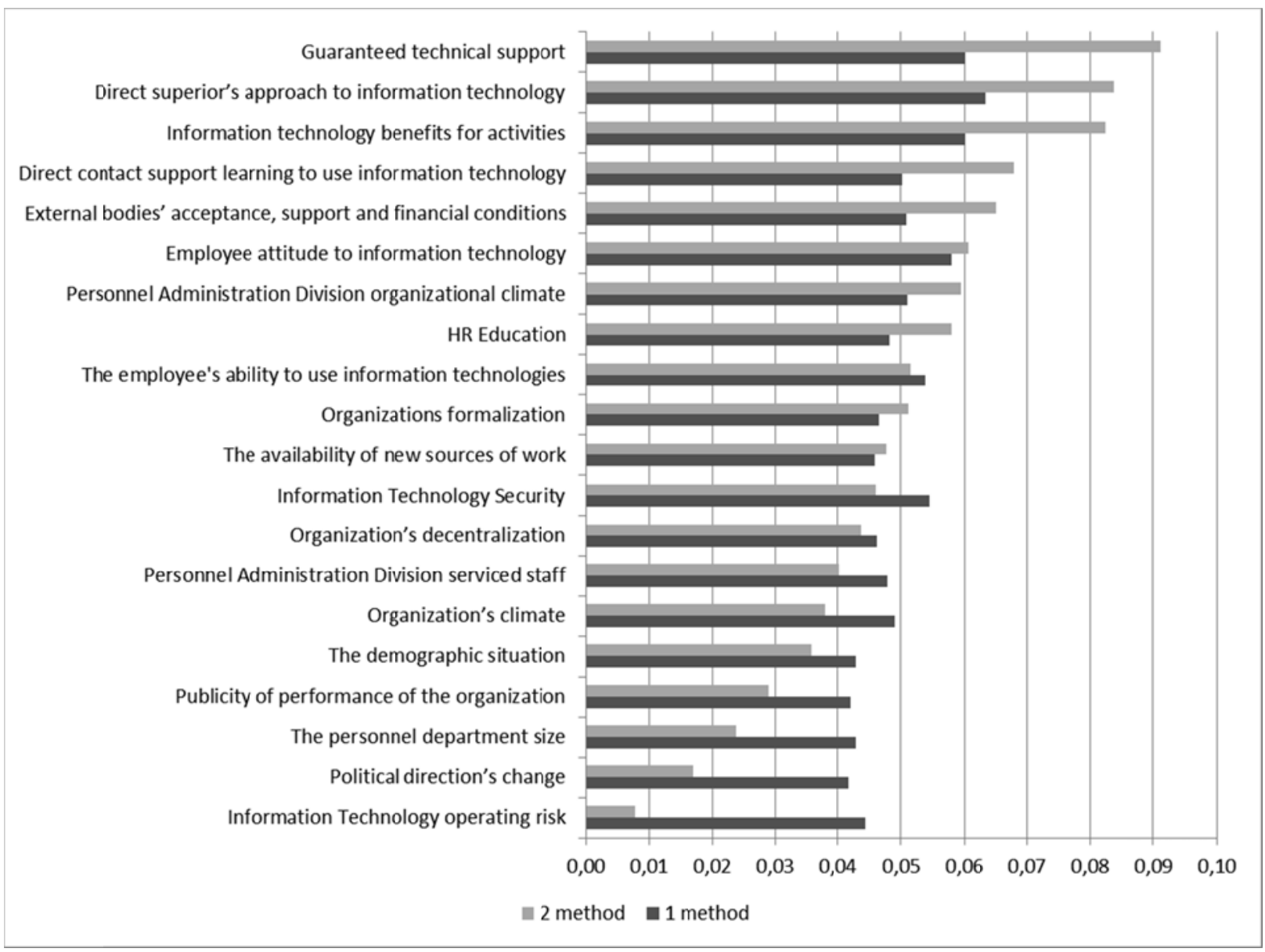

Figure 2. Relative value of environmental factors in the Lithuanian Ministries' personnel administration services

Source: own work. 
After calculation by the second method, the distribution is quite different: there are more diverse and more accurate differentiation. Consistent with the above logic, the importance of all factors that value $W_{j} \geq 0,05$, is with a high influence - positive and strong, and it is the stronger, the higher the relative estimate. All factors with lower than $W_{j} \leq 0,05$ value, have an average impact on the innovation process, and factors reached $W j=0.1$ estimate the affect absolutely poorly the progress in the innovation process (Figure 2).

When designing the study there was a decision to rely on statements of several theories about the factors that contribute to the innovation process. It can unequivocally state that such a decision was justified. Although not all chosen factors evaluated as having an impact, however, significantly extending the list of factors we saw the groups that should have been included. From the six, directly with IT related factors (the staff's ability to use information technology, information technology usage risks (eg. the fear of making a mistake, fear of the consequences of errors, and so on), information technology security, information technology benefits for activities, direct contact support learning to use information technology, guaranteed technical support (ability to consult) after the introduction of innovations) the five factors inclusion worked. After calculation by method 2 - combining experts' estimates of Question 1 and Question 2, a synthetic index was calculated, which helped to reveal more clearly the role of each factor in the general population. This basically enriched both theory and model and its use helps to adapt technology innovations' research.

\section{Conclusion}

Human resources business processes' automation and information management are becoming important organization efficiency factors. However, in reality, operating at a rapid pace on the environment, processes and work content change for ensuring the quality of the HR information, informative and user search capabilities due to wasteful organization of information management is still difficult.

The empirical results show that experts - professionals as consumers are not completely satisfied with the initiation and implementation of innovation processes. Comparison of current and target situations through a specific case study shows that because none of the innovations installation stages received equal evaluations mean that would correspond by importance to the assessments by experts provided to the stage in an ideal innovation implementation process. The highest and most consistent is innovation presentation and ensuring that maintenance and adjustment of an innovation will be perform. The biggest gap is between the analysis of user needs, presentation of demos and feedback on the process. Provision of the Law of the Republic of Lithuania on Information Resources Management to upgrade the implemented innovations according to the users' reports not brought into life. These stages are characteristic not of the IT lifecycle, but of the IT-based innovation lifecycle. In other words, this is the weakest link in the IT implementation process, which subject to attention and improvement by the provisions of innovation and changes as well as project management would facilitate the adoption of the a.m. tools in an organization. Though being formalize not seen as a positive or negative factor, certain changes in the legal and organizational environment should be pursue. Lastly, the role of initiator and innovator, attributed by exemplary personnel administration regulations in Ministries of the Republic of Lithuania, to the department manager is not realize in full to overcome existing legal obstacles and formalization. This has been evidenced in all Ministries except for the Ministry of Environment, Ministry of Finance, Ministry of Interior and Ministry of Agriculture where a possibility to initiate innovations is provided subject to the management agreement. These provided opportunities to influence decisions and change in the field of technologization their operational functions. The supplied replies suggest that possibilities of self-dependent 
determining are the least. This is not surprising especially in view of the public sector nature, information security standards, interoperability requirements, etc. However, constraint characteristic of the public sector in this sphere is witnesses by the belief that all the implementations are done at the ministerial or state level at the minimal choosing ability for employee teams. This could possibly hinder the innovation dispersion and entrenchment and should be subject to change.

Application of the innovation management and change control principles to the system life-cycle and promotion of end-user involvement in the initiation, development and implementation processes would strengthen the outcome (availability, implementation) chains in the system of improving effectiveness. The enhanced inference process in the sphere of efficacy would facilitate the achievement of better results: provide greater benefits, reduce barriers, and increase employee satisfaction. By strengthening the role of managers to increase their effectiveness, would contribute to better understanding of economic and social objectives for both workers and employers. This would as well strengthen the positive impact on the organization.

Information technology-based innovation environmental analysis indicates the need to focus on the reinforcement and replenishment of factors that encourage innovation, and the factors that weaken innovation and remove the factors that impede innovation.

There are two groups of internal factors affecting IT-based innovation application. First, the factors related to the specifics of IT-based innovations, increase and promotion of its use through approach formation, i.e. positive employee attitudes would be promote by the positive attitude of the manager towards IT and by proper presentation of innovation benefits to activities. Others that are related to its use and strengthening the usage skills - these are the benefits of technologies that were presented prior the start of installation, possibility to consult the technology operation learning process and ensure assistance using information technologies after installation. Thus, in order to achieve the effective application of IT in HR management of an organization, it is important to take into account the technological nature of innovation and eliminate the barriers that oppose it.

During research, only personnel staff (experts) of Ministries of Republic of Lithuania questioned. Further research could be perform as follows:

- External experts could be involved in order to evaluate the success of the framework application. Their insights could help to avoid subjectivity. Critical observations would contribute to the process and system effectiveness.

- Valuable information could be obtain analyzing the foreign best practices and applying assessments of the Government to Employee framework applications provided by foreign experts.

- It is likely that an investigation done at another institution or even in another country; other innovation application process and environmental aspects would be revealed.

\section{References}

Altmann, P., Engberg, R. (2015), Managing Human Resources and Technology Innovation: The Impact of Process and Outcome Uncertainties, International Journal of Innovation Science, 7(2), pp. 91-106.

Analoui, F. (2007), Strategic Human Resource Management, Thomson.

Bondarouk, T. V., Furtmueller, E. (2012), Electronic Human Resource Management: Four Decades of Empirical Evidence. In the Best Paper Proceedings of the Academy of Management Meeting 2012, ACM. 
Chui, M., Manyika, J., Bughin, J., Dobbs, R., Roxburgh, Ch., Sarrazin, H., Sands, G., Westergren, M. (2012), The Social Economy: Unlocking Value and Profuctivity Through Social Technologies, McKinsey Global Institute Report.

Codagnone, C., Undheim, T. A. (2008), Benchmarking eGovernment: tools, theory, and practice, European Journal of ePractice, 1 (4), pp.1-15.

Davison, R. M. (2005), From government to e-government: a transition model, Information Technology \& People, 18(3), pp. 280-299.

Dawes, S. S., Cook, M. E. (2007), Intergovernmental Digital Government through G2G Relationship and Applications, Encyclopedia of Digital Government, Vol. 5. Ed. AriVeikko Anttiroiko and Matti Mälkiä, pp. 1114-1119.

Dzemyda, G., Šaltenis, V., Tiešis, V. (2007), Optimizavimo metodai, Vilnius: Mokslo aidai.

European Commission (2010), Communication from the Commission. Europe 2020. A strategy for smart, sustainable and inclusive growth. COM (2010) 2020, http://ec.europa.eu/eu2020/pdf/COMPLET\%20EN\%20BARROSO $\% 20 \% 20 \% 20007 \% 2$ 0-\%20Europe\%202020\%20-\%20EN\%20version.pdf (referred on 20/04/2015).

Garcia-Carbonell, N., Martin-Alcazar, F., Sanchez-Gardey, G. (2015), Determinants of top management's capability to identify core employees, BRQ Business Research Quarterly, 18, pp. 69-80.

Griggs, V., Holden, R., Rae, J., Lawless, A. (2015), Professional learning in human resource management: problematising the teaching of reflective practice, Studies in Continuing Education, 37(2), pp. 202-217.

Habibizad Navin, A., Jafari Navimipour, N., Rahmani, A. M., Hosseinzadeh, M. (2014), Expert Grid: New Type of Grid to Manage the Human Resources and Study the Effectiveness of Its Task Scheduler, Arabian Journal for Science and Ingineering, 39(8), pp. 6175-6188.

Hidalgo, A., Albors, J. (2008), Innovation management techniques and tools: A review from theory and practice, $R \& D$ Management, 38, pp. 113-127.

Joseph, C. R., Ezzedeen, R. S. (2008), E-government and e-HRM in the public sector. In: Encyclopedia of Human Resources Information Systems: Challenges in e-HRM. New York, Hersley.

Katou, A. A. (2015), The mediating effects of psychological contracts on the relationship between human resource management systems and organisational performance, International Journal of Manpower, 36(7), pp. 1012-1033.

Kavanagh, M. J., Thite, M. (2009), Human resource information systems: basics, applications, and future directions, Thousand Oaks (Calif.): Sage Publications.

Lengnick-Hall, M. L., Lengnick-Hall, C. A., Andrade, L., Drake, B. (2009), Strategic human resource management: The evolution of the field, Human Resource Management Review, 19, pp. 64-85.

Leibetseder, B. (2011), A critical review on the concept of social technology, Social technolgies, 1(1), pp. 7-24.

Millard, J. (2013), ICT-enabled public sector innovation: trends and prospects. Proceedings of the 7th International Conference on Theory and Practice of Electronic Governance (ICE-GOV2012), Seoul, Republic of Korea, 22 - 25 October 2013, ACM Press.

Orlikowski, W. (2000), Using technology and constituting structures: a practice lens for studying technology in organizations, Organization Science, 11 (4), pp. 404-428.

Petrauskienè, R., Raipa, A. (2012), Viešojo valdymo efektyvumo elementai, Modernus viešasis valdymas (at. red. Raipa A.), Kaunas.

Puškorius, S. (2004), Criteria for estimation of the quality of management, Národohospodářský obzor / Ekonomicko-správní fakulta MU, Brno: Masarykova univerzita, Nr. 1, pp. 61-69. 
Reddington, M., Martin, G., Bondarouk, T. (2011), Linking HR strategy, e-HR goals, architectures and outcomes: a model and case study evidence, In: T. Bondarouk, H. Ruel \& J.K. Looise (eds), Electronic HRM in Theory and Practice, Advanced series in management, Vol. 8, Emerald, London, pp. 55-81.

Rogers, E. M. (2003), Diffusion of innovations, Fifth ed., Free Press.

Ruël, H. J. M., Bondarouk, T., Looise, J. C. (2004), E-HRM: Innovation or irritation An Explorative Empirical Study in Five Large Companies on Web-based HRM, Management Revue, 15(3), pp. 364-380.

Schuler, R. S., Jackson, S. E. (2007), Strategic Human Resource Management. Ed. Tyson S., Selbie D. Poeple processing systems and Human Resource Strategy. $2^{\text {nd }}$ edition, Blackwell Publishing.

Skaržauskienė, A., Tamošiūnaitè, R., Žalènienè, I. (2013), Defining social technologies ICIME 2013, RMIT University Vietnam, Ho Chi Ming Sity, Vietnam 13-14 May 2013 / edited by Blooma John, Mathews Nkhoma, Nelson Leung, Academic Conferences and Publishing International.

Solberg Soilen, K., Tontini, G. (2013), Knowledge Management Systems and Human Resource Management Policies for Innovation Benchmarking: a Study of ST Ericsson, International Journal of Innovation Science, 5(3), pp. 159-171.

Strohmeier, S. (2007), Research in e-HRM: Review and implications, Human Resource Management Review, 17(1), pp. 19-37.

Thom, N., Ritz, A. (2004), Viešoji vadyba: inovaciniai viešojo sektoriaus valdymo metmenys, Vilnius.

Walk, M., Schinnenburg, H., Handy, F. (2014), Missing in Action: Strategic Human Resource Management in German Nonprofits, VOLUNTAS: International Journal of Voluntary and Nonprofit Organizations. Official journal of the International Society for ThirdSector Research, 25(4), pp 991-1021.

Yamamoto, T.G., Ozbek, A. (2008), E-HRM as a reality in virtual world. In: Encyclopedia of Human Resources Information Systems: Challenges in e-HRM, New York, Hersley. 